Article

\title{
Cypermethrin Induces Macrophages Death through Cell Cycle Arrest and Oxidative Stress-Mediated JNK/ERK Signaling Regulated Apoptosis
}

\author{
Fang Huang, Qiaoyun Liu, Shujun Xie, Jian Xu, Bo Huang, Yihua Wu * and Dajing Xia * \\ Department of Toxicology, Zhejiang University School of Public Health, 866 Yu-Hang-Tang Road, \\ Hangzhou 310058, China; huangfang0794@163.com (F.H.); 21418122@zju.edu.cn (Q.L.); \\ xieshujun@zju.edu.cn (S.X.); hyyxxj@163.com (J.X.); huangbo1991@zju.edu.cn (B.H.) \\ * Correspondence: georgewuer@126.com (Y.W.); dxia@zju.edu.cn (D.X.); Tel.: +86-571-8820-8134 (Y.W. \& D.X.) \\ Academic Editor: Masato Matsuoka \\ Received: 15 March 2016; Accepted: 30 May 2016; Published: 17 June 2016
}

\begin{abstract}
Cypermethrin is one of the most highly effective synthetic pyrethroid insecticides. The toxicity of cypermethrin to the reproductive and nervous systems has been well studied. However, little is known about the toxic effect of cypermethrin on immune cells such as macrophages. Here, we investigated the cytotoxicity of cypermethrin on macrophages and the underlying molecular mechanisms. We found that cypermethrin reduced cell viability and induced apoptosis in RAW 264.7 cells. Cypermethrin also increased reactive oxygen species (ROS) production and DNA damage in a dose-dependent manner. Moreover, cypermethrin-induced G1 cell cycle arrest was associated with an enhanced expression of p21, wild-type p53, and down-regulation of cyclin D1, cyclin E and CDK4. In addition, cypermethrin treatment activated MAPK signal pathways by inducing c-Jun N-terminal kinase (JNK) and extracellular regulated protein kinases $1 / 2$ ERK1/2 phosphorylation, and increased the cleaved poly ADP-ribose polymerase (PARP). Further, pretreatment with antioxidant $N$-acetylcysteine (NAC) effectively abrogated cypermethrin-induced cell cytotoxicity, G1 cell cycle arrest, DNA damage, PARP activity, and JNK and ERK1/2 activation. The specific JNK inhibitor (SP600125) and ERK1/2 inhibitor (PD98059) effectively reversed the phosphorylation level of JNK and ERK1/2, and attenuated the apoptosis. Taken together, these data suggested that cypermethrin caused immune cell death via inducing cell cycle arrest and apoptosis regulated by ROS-mediated JNK/ERK pathway.
\end{abstract}

Keywords: cypermethrin; cell cycle arrest; apoptosis; oxidative stress; JNK/ERK

\section{Introduction}

Cypermethrin is the most widely used type II pyrethroid pesticide for control of agricultural and household pests [1-3]. Because of its stable property, low solubility in water, and long half-life, cypermethrin has become one of the most common contaminants in the environment [4]. It is known that cypermethrin mainly enters the watershed body such as runoff, which causes a significant increase in the concentration of cypermethrin in surface water [5]. Pyrethroids have been found to be extremely toxic to fish leading to tissue and organ lesions [6]. Cypermethrin usually causes damage to grass carp (Ctenopharyngodon idellus), such as by the necrosis of liver tissue [7]. In fish, both ion channel and ATPase have been identified as the molecular target of cypermethrin, leading to damage of normal functioning of the organs such as muscle, gills and liver in fish [8,9]. Gupta et al. have found severe impairment of the blood-brain barrier (BBB) development, maturation and function in mice treated with cypermethrin [10]. In addition, the reproductive toxicity of cypermethrin has also been demonstrated in a large number of animal experiments, and it has been proved that cypermethrin 
can cause damage to the male reproductive system, including testicular damage, sperm count, sperm motility and sperm morphology [11,12].

Excess reactive oxygen species (ROS) are produced by environmental toxicants and have been reported to induce cell death and result in human disease development. These processes include the activation of mitogen-activated protein kinase (MAPK) signaling pathways, which are observed to activate the apoptotic pathways. Previous findings revealed that cypermethrin-mediated damage of astrocytes involves $\mathrm{Ca}^{2+}$, ROS, c-Jun N-terminal kinase (JNK) and P38 pathways, leading to disruption of BBB and extracellular matrix molecule (ECM) development. Cypermethrin increased the intracellular ROS generation and $\mathrm{Ca}^{2+}$ in rat astrocytes. The JNK1/2 and P38 are subsequently activated to induce apoptosis in rat astrocyte cells [13]. Mun et al. also reported that cypermethrin causes oxidative stress-mediated neurotoxicity in rats, which is associated with increased ROS production [14]. Cypermethrin has also been reported to cause hepatocytes toxicity in zebrafish via oxidative stress, DNA damage and induction of apoptotic gene expression, which will facilitate to fully understand aquatic toxicological mechanism of cypermethrin in fish [15]. In African clawed frog (Xenopus lavies) embryos, cypermethrin resulted in DNA adduct accumulation in the presence of ultraviolet radiation $\mathrm{b}$ (UVB), which correlated with the induction of highly conserved genes involved in cell cycle arrest, DNA repair regulation and apoptosis (p53) [16]. The p53 protein can induce cell cycle arrest in the G0/G1 phase by upregulating the expression of p21 and promote apoptosis. Cypermethrin also produced genotoxic effects in root meristem cells of Hordeum vulgare L. according to the types and percentage of chromosomal aberrations [17].

However, the immunotoxic effects of cypermethrin on macrophages have not been well studied. To address it, we systematically examined the immunotoxicity of cypermethrin by focusing on the effects of cypermethrin on cell cycle arrest and apoptosis in macrophage-like RAW 264.7 cells. Our findings reveal a novel aspect of toxicological mechanism mediated by cypermethrin in macrophages.

\section{Results}

\subsection{Cytotoxic Effect of Cypermethrin, Reactive Oxygen Species (ROS) Production and Apoptosis Induction in} RAW 264.7 Cells

To evaluate cypermethrin-induced cytotoxicity in macrophage cells, we first used the 3-(4,5-dimethyl thiazol-2-yl-)-2,5-diphenyl tetrazolium bromide (MTT) assay to measure the viability of RAW 264.7 cells. Treatment of RAW 264.7 cells with cypermethrin for $24 \mathrm{~h}$ at concentrations for up to $200 \mu \mathrm{M}$ displayed no significant changes in cell survival compared to the control cells (Figure 1A). At $48 \mathrm{~h}$, we observed significant reduction of the relative cell viability after exposure to 100 or $200 \mu \mathrm{M}$ cypermethrin $(83 \% \pm 3 \%$ and $77 \% \pm 7.2 \%$, respectively). Raw 264.7 cells treated with cypermethrin at lower concentrations (from 12.5 to $50 \mu \mathrm{M}$ ) for $48 \mathrm{~h}$ showed no significant change in cell survival compared to the control (Figure 1A). Next, to validate the inhibitory effect of cypermethrin on cell growth was related to apoptosis, the morphologic changes of RAW cell apoptosis treated with cypermethrin $(0,50,100$ and $200 \mu \mathrm{M})$ were stained with Hoechst 33342. The results showed treatment with cypermethrin induced more cell apoptosis featured by nuclear fragmentation, chromatin condensation, and apoptotic body formation than the untreated control cells (Figure 1B).

In order to understand the mechanisms underlying the cytotoxic effects observed above, we focused on cypermethrin-mediated ROS generation and oxidative stress in RAW 264.7 cells. As shown in Figure 1C, the levels of intracellular ROS increased in a dose-dependent manner (50, 100, and $200 \mu \mathrm{M}$ resulted in $101.3 \% \pm 11 \%, 123 \% \pm 3.6 \%$, and $196 \% \pm 22.3 \%$, respectively, compared to control) after exposure of cells to cypermethrin for $1 \mathrm{~h}$. Furthermore, pretreatment with $5 \mathrm{mM} \mathrm{N}$-acetylcysteine (NAC; a potent antioxidant) partially blocked cypermethrin-induced toxicity (Figure 1D) and apoptotic body formation induced by $200 \mu \mathrm{M}$ cypermethrin treatment (Figure 1B). 
A

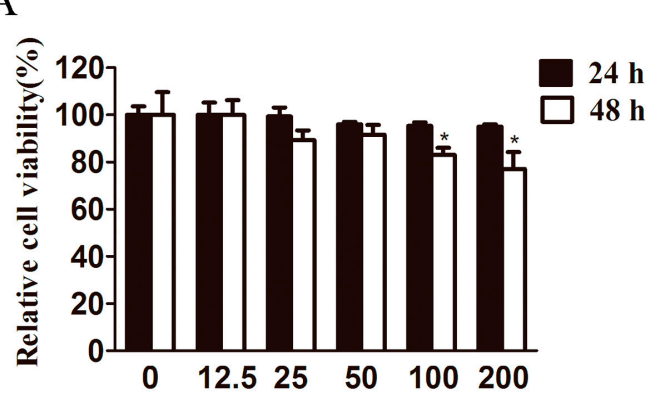

Cypermethrin $(\mu \mathrm{M})$

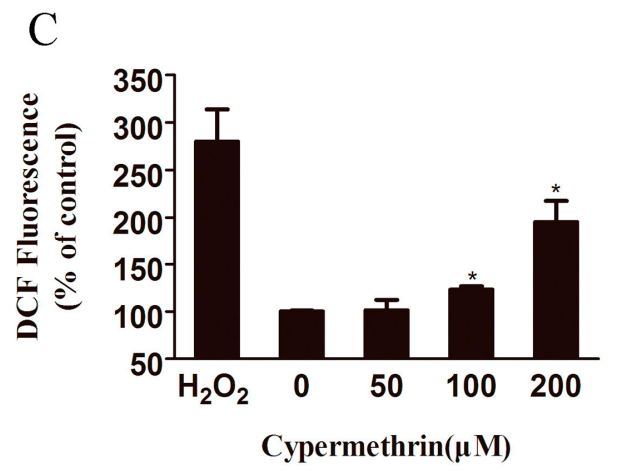

B

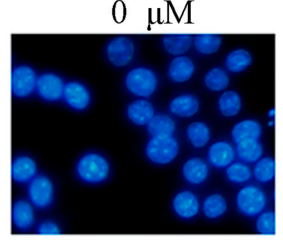

$100 \mu \mathrm{M}$

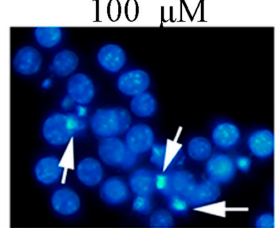

NAC

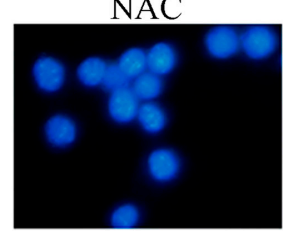

D

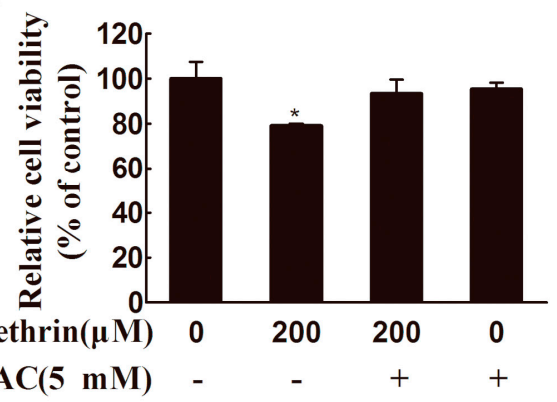

Figure 1. Effect of cypermethrin on cell viability and reactive oxygen species (ROS) production in RAW 264.7 cells. (A) The cells were treated with 0-200 $\mu \mathrm{M}$ cypermethrin for 24 or $48 \mathrm{~h}$, and cell viability was assessed by 3-(4,5-dimethyl thiazol-2-yl-)-2,5-diphenyl tetrazolium bromide (MTT) assay; (B) Cells were plated in 6-well plates and treated with cypermethrin $(0,50,100$ and $200 \mu \mathrm{M})$ in the presence or absence of $5 \mathrm{mM}$ NAC. $48 \mathrm{~h}$ later, cells were treated with Hoechst 33342 staining at $1 \mathrm{mg} / \mathrm{mL}$ for $30 \mathrm{~min}$ and then observed under the inverted fluorescence microscope (Original magnification, $\times 400$ ); The cell nucleus change of apoptotic cell is shown by the arrows; (C) RAW 264.7 cells were treated with 0-200 $\mu \mathrm{M}$ cypermethrin for $1 \mathrm{~h}$. Then Cells were exposed to 2,7-dichlorofluorescin diacetate (DCFH-DA) (10 $\mu \mathrm{M})$ for $30 \mathrm{~min}$. The fluorescence intensity was measured in a SYNERGY-HT multiwell plate reader at excitation and emission wavelengths of 485 and $528 \mathrm{~nm}$, respectively. Untreated cells were used as negative controls and cells treated with $1 \mathrm{mM} \mathrm{H}_{2} \mathrm{O}_{2}$ as positive controls (D) RAW 264.7 cells were treated for $48 \mathrm{~h}$ with dimethylsulfoxide (DMSO), $200 \mu \mathrm{M}$ cypermethrin only, pretreated with $5 \mathrm{mM}$ $\mathrm{N}$-acetylcysteine (NAC) before $200 \mu \mathrm{M}$ cypermethrin treatment, or $5 \mathrm{mM}$ NAC only. Then Cell viability was assessed using MTT assay. The data are presented as the means \pm standard deviation of three independent experiments. ${ }^{*} p<0.05$ as compared with vehicle alone.

To confirm whether apoptosis is involved in cypermethrin-induced cell death, RAW 264.7 cells were treated with cypermethrin at different concentrations for $48 \mathrm{~h}$ and their apoptosis was analyzed by Annexin V and propidium iodide (PI) double staining. As shown in Figure 2, higher concentrations of cypermethrin (100 and $200 \mu \mathrm{M})$ induce obvious apoptosis of RAW 264.7 cells, which could be partially reversed by NAC (5 mM). The results showed that the inhibitory effect of cypermethrin on the macrophage proliferation may be at least partially due to apoptosis induction, which involved cypermethrin-induced ROS production causing RAW cell death. 


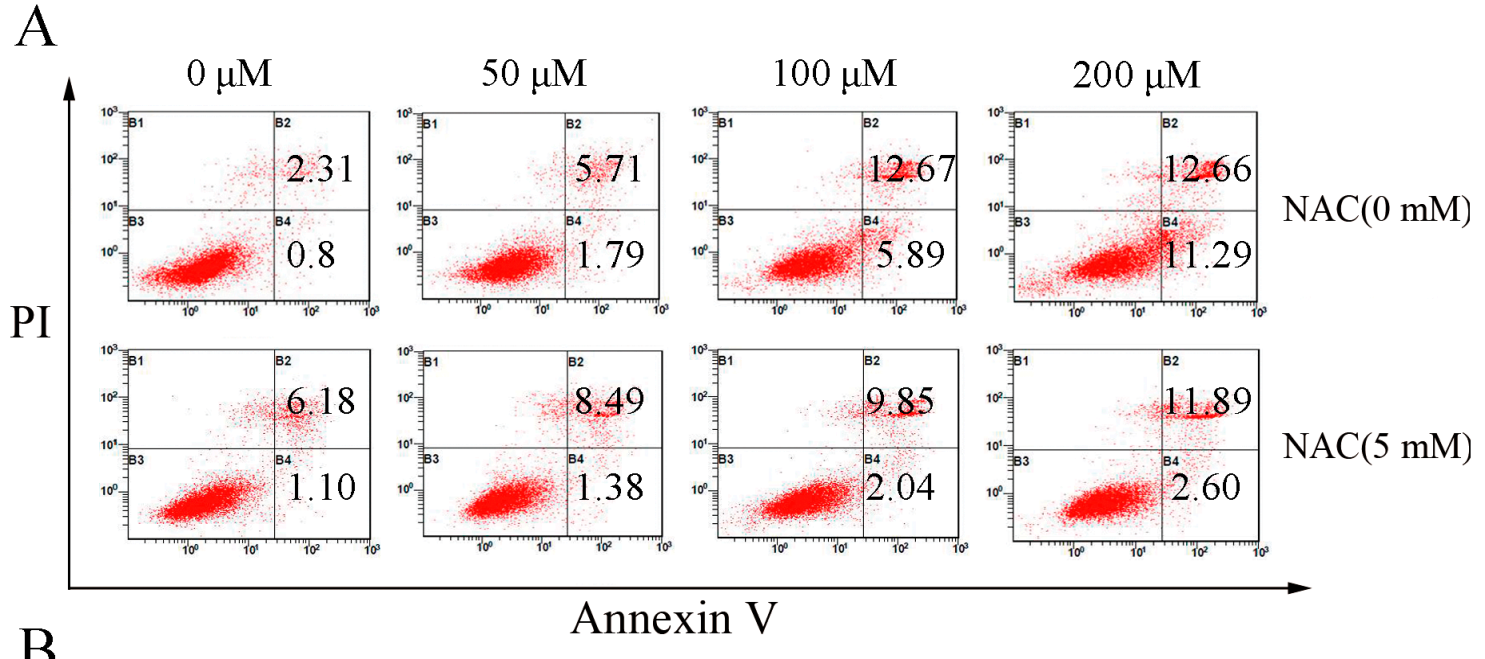

$\mathrm{B}$

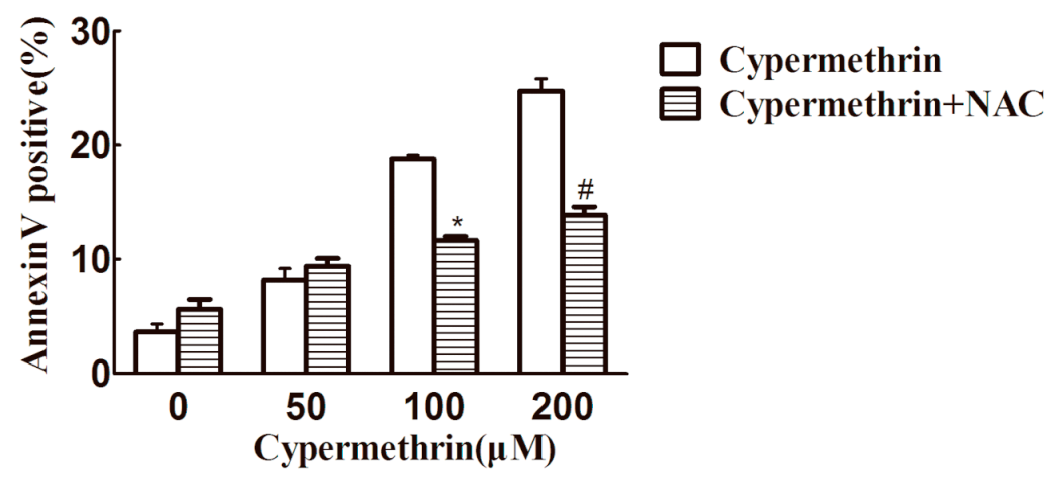

Figure 2. Cypermethrin induced apoptosis in RAW 264.7 cells. The cells were treated with cypermethrin in the presence or absence of $5 \mathrm{mM} \mathrm{NAC}$ for $48 \mathrm{~h}$. In addition, the percentage of apoptotic cells was measured by Fluorescence Activating Cell Sorter (FACS) analysis using Annexin V/PI staining (A); Data were presented as means \pm SD from three independent experiments $(\mathbf{B}) .{ }^{*} p<0.05$ as compared with $100 \mu \mathrm{M}$ cypermethrin alone. \# $p<0.05$ as compared with $200 \mu \mathrm{M}$ cypermethrin alone.

\subsection{Induction of G1 Cell Cycle Arrest in Raw 264.7 Cells by Cypermethrin}

After treatment with cypermethrin, cell cycle analysis was performed by flow cytometry. As shown in Figure 3A, exposure of RAW 264.7 cells to cypermethrin for 48h resulted in a significant increase in G1 phase cells in a dose dependent manner as compared to the non-treated controls $(p<0.05)$. Higher percentage of cells arrested in G1 was found when cells were treated with $200 \mu \mathrm{M}$ cypermethrin. Treatment with 100 and $200 \mu \mathrm{M}$ of cypermethrin for $48 \mathrm{~h}$ significantly up-regulated p53 protein level in RAW 264.7 cells (Figure 3B). The expression of p21 of RAW 264.7 cells treated with 100 and $200 \mu \mathrm{M}$ of cypermethrin was up-regulated correspondingly at $48 \mathrm{~h}$. As cell cycle progression is mediated by cyclin-dependent kinases (CDKs) complexed with corresponding cyclins [18], we next examined whether cypermethrin modulates the protein levels of G1 CDKs and cyclins in RAW cells. As shown in Figure 3B, cypermethrin treatment for $48 \mathrm{~h}$ resulted in a moderate to strong decrease in the expression of CDK4, cyclin D1 and cyclin E. Pretreatment with $5 \mathrm{mM}$ NAC could partially reverse cypermethrin-induced G1 phase cell cycle arrest (Figure 3C). Together, these results suggest that cypermethrin is able to induce G1 arrest in RAW 264.7 cells. 


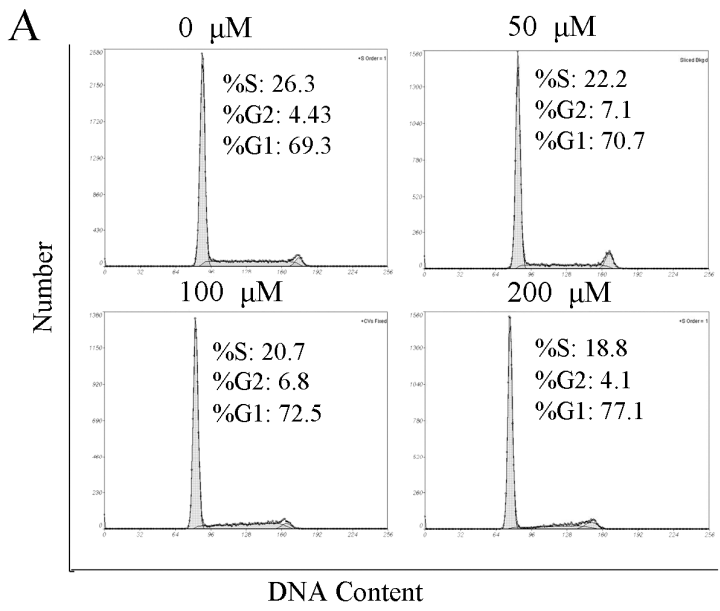

B
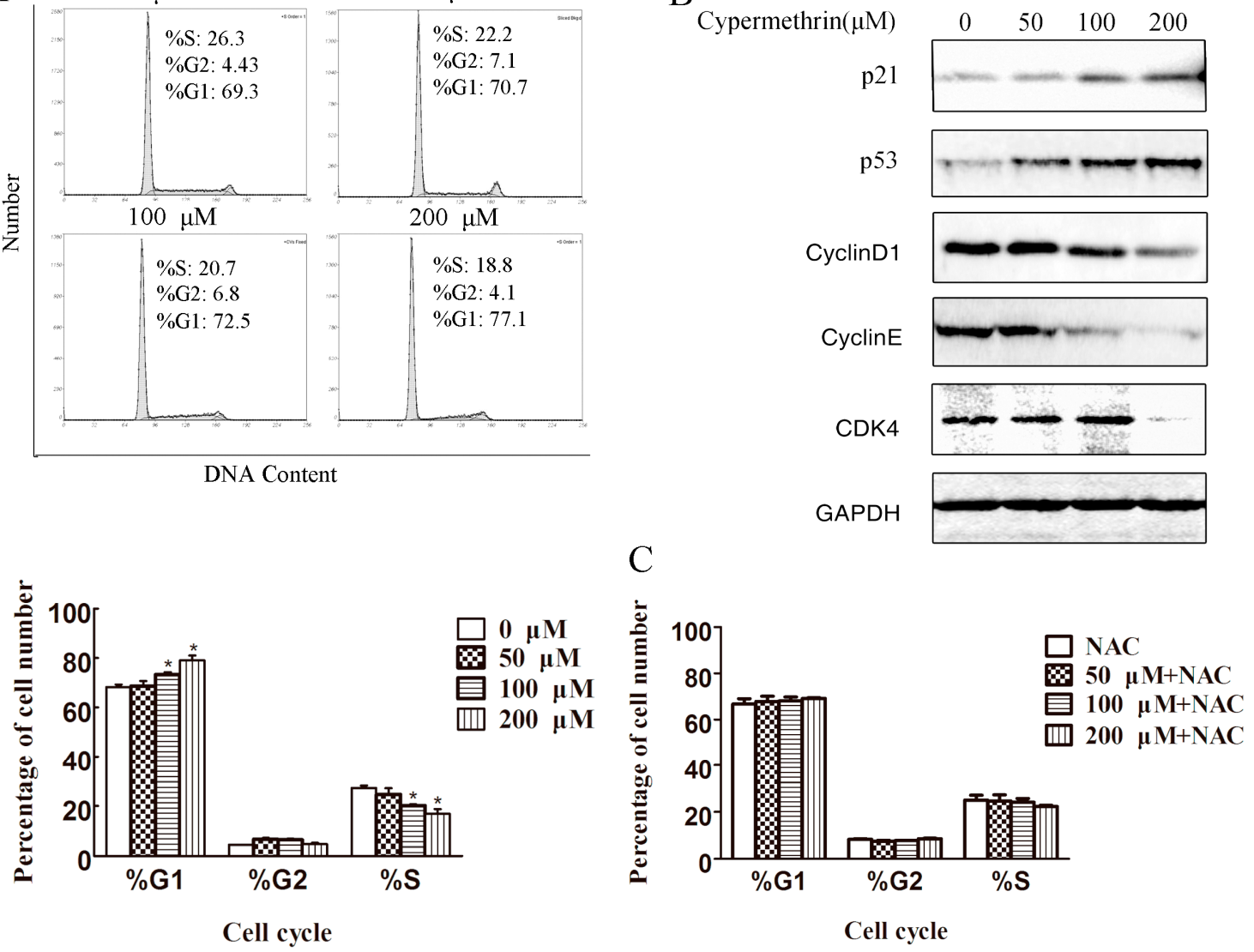

Figure 3. Cypermethrin leaded to G1 cell cycle arrest in RAW 264.7 cells. RAW 264.7 cells were treated with cypermethrin for $48 \mathrm{~h}$ (A). After treatment, cells were harvested and processed for cell cycle distribution analysis using flow cytometry; (B) Expression levels of p53 and G1 phase cell cycle regulators in RAW cells treated with cypermethrin. RAW cells were treated with or without cypermethrin for $48 \mathrm{~h}$. After treatment, cells were harvested and cell lysates were subjected to the analysis of cell cycle regulatory proteins of G1-phase and p53 using western blot analysis; and (C) Cells were pretreated with $5 \mathrm{mM} \mathrm{NAC}$ for $1 \mathrm{~h}$ and treated with cypermethrin for $48 \mathrm{~h}$. Cells were analyzed for cell cycle distribution. Quantitative data shown for G1, G2 and S phase cell population were representive of three independent experiments. ${ }^{*} p<0.05$ as compared with vehicle alone.

\subsection{Cypermethrin-Induced ROS Generation Mediated RAW Cell Apoptosis via Causing DNA Damage}

Because oxidative DNA damage is a mediator of cell death, the effect of cypermethrin-induced ROS generation on the DNA damage was investigated. After $48 \mathrm{~h}$ exposure to cypermethrin, we performed the Comet assay to determine whether cypermethrin induces DNA damage. Figure 4A showed that chromosomal DNA strand breaks were evident by cypermethrin at concentrations from 50 to $200 \mu \mathrm{M}$ in RAW 264.7 cells, shown by the formation of tail DNA in cells treated with cypermethrin. Pretreating with NAC could efficiently prevent DNA damage in RAW cells by $200 \mu \mathrm{M}$ cypermethrin treatment. Previous studies indicated that $\gamma \mathrm{H} 2 \mathrm{AX}$ was an early sensitive indicator of DNA double-strand breaks (DSBs) induced by chemical agents $[19,20]$. Here we further examined changes of $\gamma \mathrm{H} 2 \mathrm{AX}$ protein by immunofluorescence and immunobloting. As shown in Figure 4B, cypermethrin treatment for $48 \mathrm{~h}$ induced enhanced $\gamma \mathrm{H} 2 \mathrm{AX}$ protein levels in a dose-dependent manner. In addition, $\gamma \mathrm{H} 2 \mathrm{AX}$ expression by $200 \mu \mathrm{M}$ cypermethrin exposure was attenuated in RAW cells pre-treated with NAC. Western blot analysis also showed that cypermethrin resulted in a significantly increase in the level of $\gamma \mathrm{H} 2 \mathrm{AX}$ as compared with the control group (Figure $4 \mathrm{C}$ ). These findings revealed that cypermethrin-induced oxidative stress could trigger DNA damage. 
A
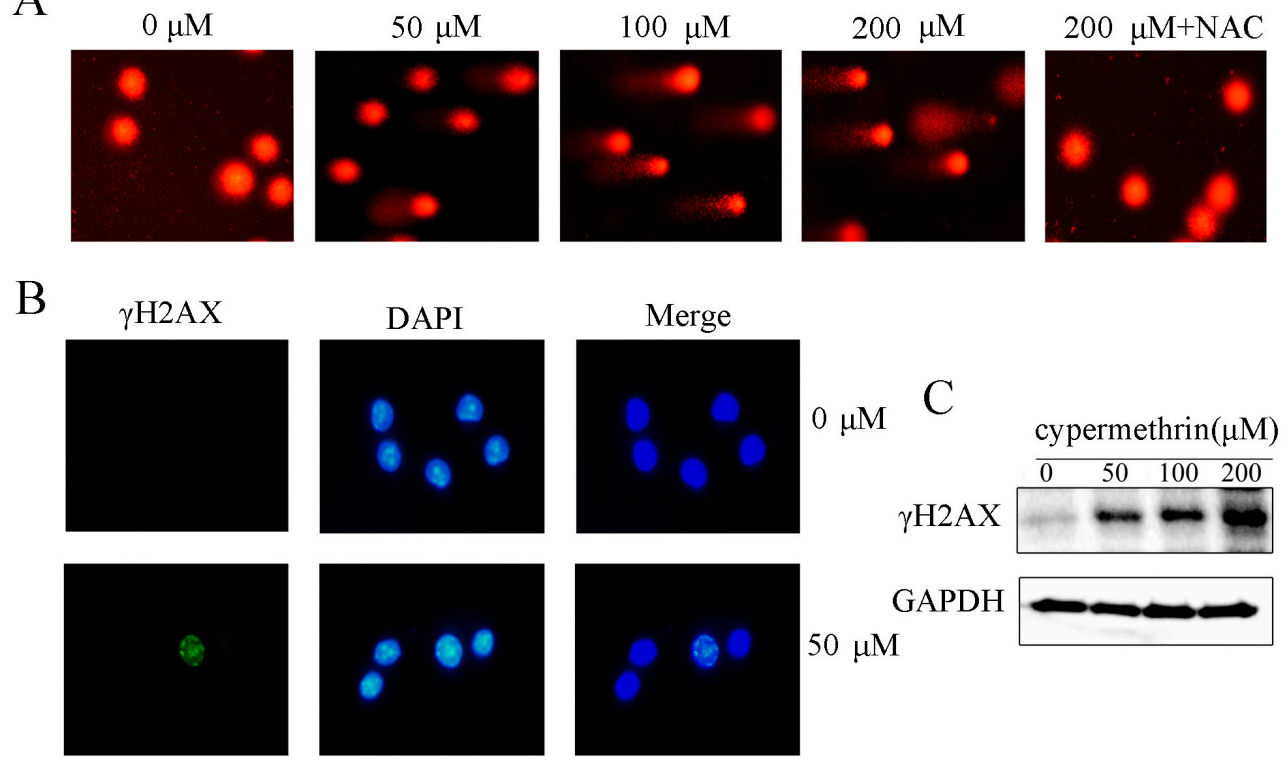

GAPDH
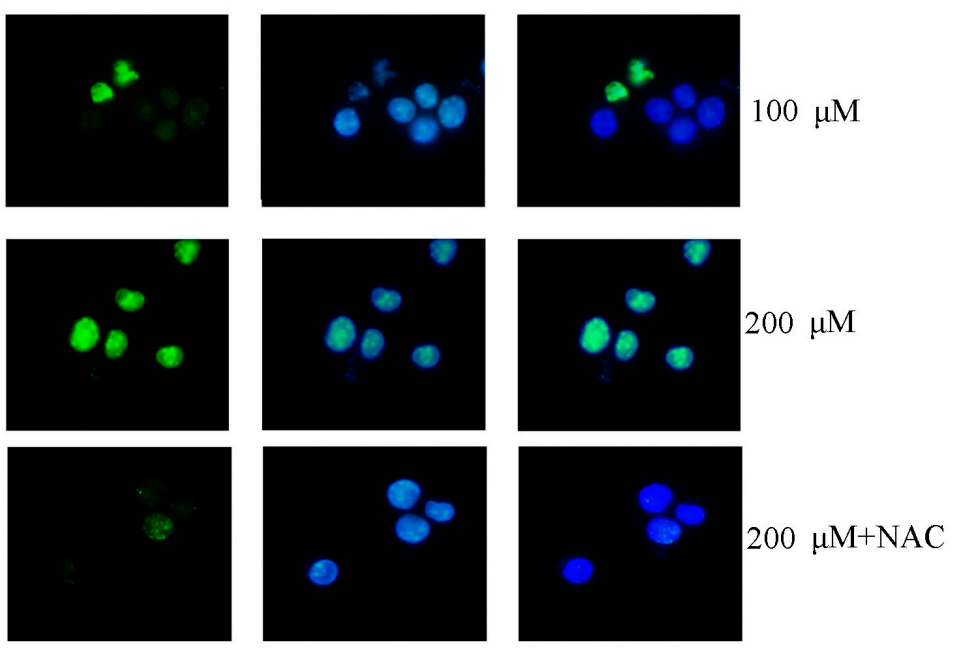

Figure 4. Cypermethrin-induced ROS generation triggered oxidative DNA damage. (A) The comet images of RAW cells when treated with 0-200 $\mu \mathrm{M}$ cypermethrin, or pretreated with $5 \mathrm{mM}$ NAC before $200 \mu \mathrm{M}$ cypermethrin treatment for $48 \mathrm{~h}$; (B) After exposure to various concentrations of cypermethrin and pretreated with $5 \mathrm{mM}$ NAC before $200 \mu \mathrm{M}$ cypermethrin treatment for $48 \mathrm{~h}$, the $\gamma \mathrm{H} 2 \mathrm{AX}$-foci staining in each cell increased with higher concentrations of cypermethrin. The $\gamma \mathrm{H} 2 \mathrm{AX}$ foci exhibited in green stained by fluoresce isothiocyanate (FITC), and the nuclei exhibited in blue stained by DAPI. (Magnification, $\times 400$ ); (C) The expression level of $\gamma \mathrm{H} 2 \mathrm{AX}$ was also examined by Western blot in RAW cells treated with cypermethrin for $48 \mathrm{~h}$.

\subsection{MAPK Signaling Pathway Involved in Cypermethrin-Induced RAW Cell Apoptosis}

MAPK signaling pathway plays a crucial role in a variety of toxic insults-induced apoptosis, and oxidative stress is known to activate the MAPK families by protein phosphorylation [21]. Therefore, the correlation between oxidative stress and the subsequent activation of the MAPKs was investigated. As shown in Figure 5A, treatment of RAW cells with $200 \mu \mathrm{M}$ cypermethrin for 15-30 min significantly increased the JNK phosphorylation and then rapidly decreased. ERK1/2 phosphorylation increased transiently at $15 \mathrm{~min}$ to $1 \mathrm{~h}$ and then rapidly decreased. Pretreatment with NAC could abrogate the effects of cypermethrin on the activation of JNK and ERK1/2, which indicated that ROS is critical for JNK and ERK1/2 activation induced by cypermethrin (Figure 5B). Moreover, NAC was also found 
to significantly reduce the PARP cleavage caused by cypermethrin (Figure 5C). The JNK inhibitor (SP600125), and ERK1/2 inhibitor (PD98059), could remarkably prevent the phosphorylation level of JNK and ERK1/2 induced by cypermethrin (Figure 6A,B). In addition, both inhibitors could effectively attenuate cypermethrin-induced cell apoptosis (Figure 6C). Therefore, these results showed that ROS production may contribute to the activation of the JNK/ERK signaling pathway and lead to RAW cell apoptosis induced by cypermethrin.

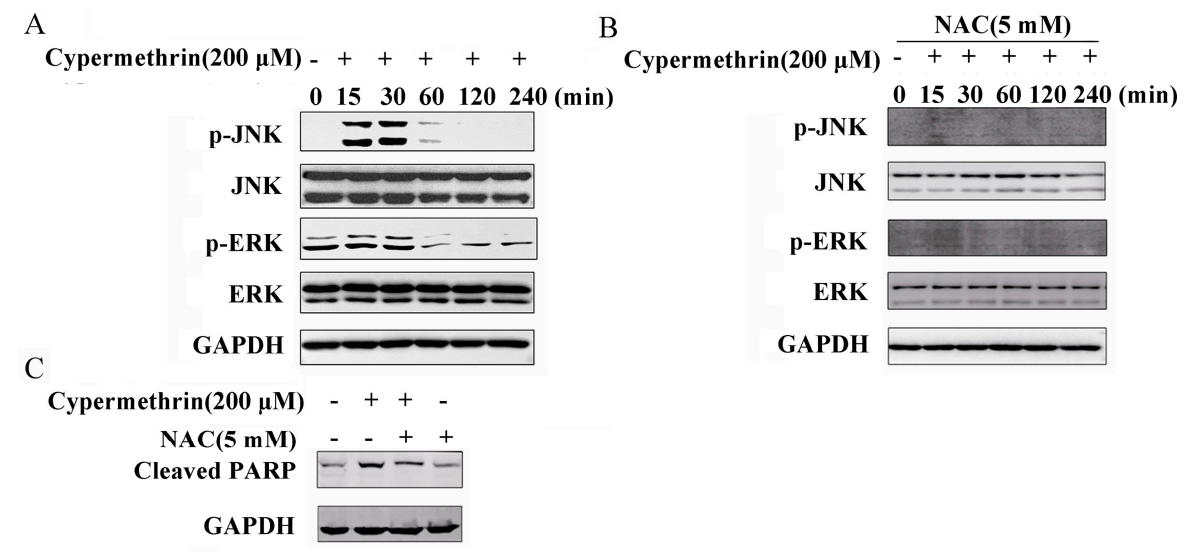

Figure 5. Cypermethrin induced activations of JNK and ERK MAPK signaling pathways. (A) RAW cells were treated with or without $200 \mu \mathrm{M}$ cypermethrin for 15-240 min, and JNK, ERK1/2 phosphorylation levels were examined by Western blot; (B) Furthermore, cells were pretreated with 5 mM NAC for $1 \mathrm{~h}$ and exposed to cypermethrin, and the phosphorylation levels of JNK, ERK1/2 were examined by Western blot. In addition, (C) Cells were treated for $48 \mathrm{~h}$ with DMSO, $200 \mu \mathrm{M}$ cypermethrin only, pretreated with $5 \mathrm{mM}$ NAC before $200 \mu \mathrm{M}$ cypermethrin exposure, or $5 \mathrm{mM}$ NAC only. The cleaved poly ADP-ribose polymerase (PARP) was examined by Western blot.

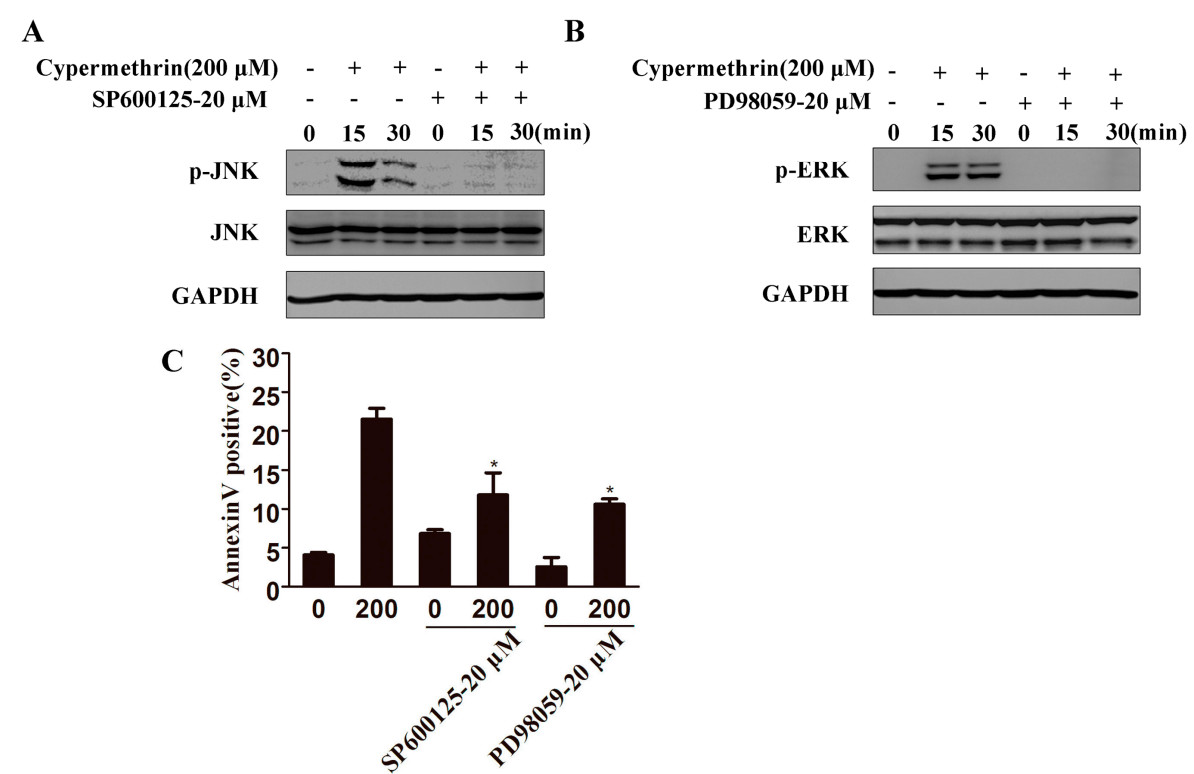

Figure 6. Treatment of cells with JNK/ERK-MAPK specific inhibitor prevented cypermethrin-induced apoptosis. (A)RAW cells were treated with JNK inhibitor (SP600125) or ERK1/2 inhibitor (PD98059) for $1 \mathrm{~h}$ prior exposed to cypermethrin $(200 \mu \mathrm{M})$. The levels of JNK and ERK phosphorylation were detected by Western blot analysis (A,B); Annexin V-FITC positive cells were analyzed by flow cytometry (C). Data were presented as means $\pm \mathrm{SD}$ from three independent experiments. ${ }^{*} p<0.05$ as compared with treatment with $200 \mu \mathrm{M}$ cypermethrin. 


\section{Discussion}

Macrophages are highly plastic and their function dependents on the external environment. Triggering the activation of macrophages plays a major role in eliminating the invading pathogens or the alien stimulation. The classically activated macrophages produce high levels of proinflammatory cytokines such as tumor necrosis factor- $\alpha$ (TNF- $\alpha$ ), interleukin-1 $\beta$ (IL-1 $\beta)$, IL-6, and reactive oxygen to protect host against the infection [22]. However, once cypermethrin causes toxicity effect in macrophage and thus affect the function of macrophage, the resolution of inflammation must be impaired. Understanding the molecular mechanism of toxical effect on macrophage may provide new insights on immunological pathology induced by cypermethrin.

The present study demonstrated that the toxicological mechanism induced by cypermethrin- in RAW 264.7 cells, involving cell cycle arrest and apoptosis. In addition, cypermethrin induced ROS generation and oxidative stress in RAW 264.7 cells. Our study confirmed that NAC pretreatment reduces the toxicity caused by cypermethrin via prevention of elevated oxidative stress. Thus, specific antioxidants may be helpful in therapy of cypermethrin-induced toxicity. DNA damage occurred in cells even at low concentration for persistent treatment. Therefore, the above will favor to understand the mechanism of cypermethrin-induced toxicity through oxidative stress, cell cycle arrest and apoptosis in macrophage.

Oxidative stress is elicited by the imbalance excessive ROS production, which can subsequently result in significant damage to cell structure. In most cases, oxidative stress is implicated in a wide variety of biological and pathological processes such as apoptosis and nervous system injuries [23]. Organisms protect themselves against the destructive effects of activated ROS by several antioxidant enzymes including catalase (CAT), glutathion peroxidase (GPx) and superoxide dismutase (SOD) [24]. NAC as an antioxidant has been reported to enhance the activity of tissue specific antioxidant enzymes such as SOD [25,26]. NAC can also inhibit the NADPH oxidase activation, a source of ROS [27]. In general, NAC is used to identify the role of ROS in various biological responses. In the current study, pretreatment with antioxidant NAC could effectively but not fully reverse cypermethrin-induced cytotoxic responses. Therefore, it demonstrated that ROS played an important role in cypermethrin-induced apoptosis.

It is generally accepted that there is a close relationship between oxidative stress and DNA damage [28]. ROS interact with DNA, potentially leading to serious consequences for the cells [29]. ROS can induce oxidative damage to DNA, including strand breaks and nucleotide modifications, especially in sequence with high guanosine content [30]. The comet assay is one of the most simple and sensitive methods for detecting DNA damage developed in recent years [31]. Phosphorylation of histone variant $\mathrm{H} 2 \mathrm{AX}(\gamma \mathrm{H} 2 \mathrm{AX})$ is very important for recruitment of checkpoint proteins and DNA repair to the DNA damage sites [32,33]. Cypermethrin has been reported to induce ROS and DNA damage in adult zebrafish [15]. In our study, we evaluated the toxicity of cypermethrin using both of these methods. We found that cypermethrin -induced DNA damage in the RAW cells even at low concentrations. The comet assay revealed a dose-dependent increase of OTM, and significant $\gamma \mathrm{H} 2 \mathrm{AX}$ foci formation was observed after cypermethrin treatment for long time. The percentage of cells containing $\gamma \mathrm{H} 2 \mathrm{AX}$ foci was significantly greater compared to the control group. Western blot assay also demonstrated that the expression of $\gamma \mathrm{H} 2 \mathrm{AX}$ increased in a dose dependent manner. These experiments indicated that cypermethrin leaded to DNA damage in RAW cells and the damage was correlated with cypermethrin concentrations.

p53 is a tumor suppressor gene which is often dysfunctional in tumor cells [34]. Our study reported that the representative tumor suppressor p53 was up-regulated. The cyclin-dependent protein kinase inhibitor $\mathrm{p} 21$ is one of p53-inducible gene products [35]. It is reported that up-regulation of wild-type p53 triggers p21 protein accumulation, resulting in G0/G1 phase cell cycle arrest in MCF-7 cells [36]. The p53/p21 signal pathway is implicated in the regulation of cell cycle [37]. p53 is quickly activated to largely accumulate in the nucleus, when cells receive serious DNA damage, hypoxia and 
oxidative damage. Once DNA damage cannot be repaired, cells will undergo apoptosis and are then eliminated from tissues [38].

The MAPK signaling pathway is comprised of a family of protein kinases (including: JNK, ERK1/2 and p38-MAPK), which play an important role in the control of cellular differentiation, proliferation, and cell survival to death [39]. Moreover, several studies have suggested that oxidative stress can activate JNK and result in apoptosis [40,41]. However, there are few studies to investigate the toxicity of cypermethrin -induced macrophage cell death and the detailed mechanism between oxidative stress and the activation of MAPKS pathways in cypermethrin-induced macrophage cell death. The present study found that remarkably increased the expression of phosphory JNK and ERK1/2 in RAW cells, which could be reversed by NAC. Furthermore, pretreatment with NAC partially blocked the PARP activation and apoptosis. The specific JNK and ERK-MAPK inhibitor effectively attenuated cytotoxicity and apoptosis events. These results demonstrated JNK/ERK MAPK pathways were involved in the cypermethrin-induced oxidative stress triggered macrophage apoptosis.

\section{Materials and Methods}

\subsection{Cell Culture}

RAW 264.7 cells obtained from the ATCC were cultured in Dulbecco's Modified Eagle Medium (DMEM) supplemented with 10\% fetal bovine serum (Bioind, Kibbutz Beit-Haemek, Israel) and penicillin $(100 \mathrm{U} / \mathrm{mL}) /$ streptomycin $(100 \mathrm{mg} / \mathrm{mL})$ under standard conditions (humidified incubator at $37^{\circ} \mathrm{C}$ in $5 \% \mathrm{CO}_{2} / 95 \%$ air). Cells were seeded to $6-, 12-$, or 96 -well cell culture plates and allowed to grow for $24 \mathrm{~h}$ prior to treatment with cypermethrin.

\subsection{Chemicals and Antibodies}

Cypermethrin, cleaved-PARP antibody and $N$-acetylcysteine (NAC) were purchased from Sigma; $\gamma \mathrm{H} 2 \mathrm{AX}$ antibody was purchased from Millipore (Billerica, Bedford, MA, USA); Mouse- or rabbit-monoclonal antibodies specific for phospho-JNK1/2, JNK1/2, phospho-ERK1/2, ERK1/2, p53, p21, cyclin D1, cyclin E, and CDK4 were purchased from Cell Signaling Technology (Boston, MA, USA). 2, 7-dichlorofluorescin diacetate (DCFH-DA) was purchased from Sigma (St. Louis, MO, USA). The Annexin V-fluoresce isothiocyanate (FITC)/propidium iodide (PI) apoptosis detection kit, cell cycle staining kit and glyceraldehyde-3-phosphate dehydrogenase (GAPDH) antibody were obtained from Multisciences Biotechnology (Hangzhou, China).

\subsection{Cell Viability Assay}

Cells were seeded into 96-well culture plates at a density of $1 \times 10^{5}$ cells/well and then treated with cypermethrin in the absence or present $(1 \mathrm{~h}$ pretreatment) of NAC $(5 \mathrm{mM})$. After $48 \mathrm{~h}$ treatment, $20 \mu \mathrm{L}$ ( $5 \mathrm{mg} / \mathrm{mL}$ ) of 3-(4,5-dimethyl thiazol-2-yl-)-2,5-diphenyl tetrazolium bromide (MTT) was added to each well and incubated at $37^{\circ} \mathrm{C}$ for $4 \mathrm{~h}$. After the formazan was dissolved, absorbance at $490 \mathrm{~nm}$ was measured using an enzyme-linked immunosorbent assay (ELISA) microplate reader (TECAN Infinite M200, Bio-Rad, Hercules, CA, USA).

\subsection{Cell Cycle Analysis}

RAW 264.7 cells were seeded and treated with designed doses of cypermethrin for $48 \mathrm{~h}$. After treatment, cells were trypsinized, centrifuged at $300 \times g$ for $5 \mathrm{~min}$ and washed with phosphate belanced solution (PBS), then re-suspended in $1 \mathrm{~mL}$ of cold $70 \%(v / v)$ ethanol, and stored at $4{ }^{\circ} \mathrm{C}$ for at least $2 \mathrm{~h}$. Then, the fixed cells were washed with $2 \mathrm{~mL}$ PBS and incubated for $15 \mathrm{~min}$. After centrifugal, the cells were added $1 \mathrm{~mL}$ Regent A of cell cycle staining kit. Following mixing, cells were incubated in dark condition for $30 \mathrm{~min}$ at $37^{\circ} \mathrm{C}$. The cells were then analyzed using a FC500 MCL machine (Beckman Coulter, Brea, CA, USA). 


\subsection{Analysis of Apoptosis}

At the end of treatment with cypermethrin for $48 \mathrm{~h}$ in the absence or presence of $5 \mathrm{mM} \mathrm{NAC}$, cells were harvested and washed three times with PBS, then resuspended in $500 \mu \mathrm{L}$ binding buffer with $10 \mu \mathrm{L}$ PI and $5 \mu \mathrm{L}$ Annexin VFITC. Cells were incubated in the dark at room temperature for $5 \mathrm{~min}$. The cells were then immediately analyzed by using a FC500 MCL machine (Beckman Coulter).

\subsection{Comet Assay}

The Comet assay has been well established for measuring DNA damage [42]. Briefly, cells were seeded in 12-well plates and treated with cypermethrin as designated. Then the cells were collected, and resuspended in $50 \mu \mathrm{L}$ low melting point (LMP) agarose. In addition, $75 \mu \mathrm{L}$ LMP-cell suspension was immediately pipetted onto a fully frosted microscope slide. A coverslip was then submerged in pre-chilled lysis solution (1\% Triton X-100, $2.5 \mathrm{M} \mathrm{NaCl}$, and $10 \mathrm{mM}$ EDTA, pH 10) for $1.5 \mathrm{~h}$ at $4{ }^{\circ} \mathrm{C}$. The slides were soaked in prechilled unwinding and electrophoresis buffer for $20 \mathrm{~min}$, then were subjected to electrophoresis for $30 \mathrm{~min}$ at $300 \mathrm{~mA}$. When electrophoresis was over, the slides were washed three times with $\mathrm{ddH}_{2} \mathrm{O}$, and incubated in $70 \%$ alcohol for $5 \mathrm{~min}$. Then it was stained with DAPI for $20 \mathrm{~min}$, and nuclear images were visualized and captured using an Olympus AX70 fluorescent microscope (Olympus, Tokyo, Japan).

\subsection{Immunofluorescence Microscopy}

After various treatments, cells were washed with PBS and fixed in $4 \%$ paraformaldehyde for $15 \mathrm{~min}$, permeabilized with $0.5 \%$ triton and blocked with $3 \%$ bovine serum albumin (BSA) for $30 \mathrm{~min}$. The samples were incubated with 1:3000 mouse monoclonal anti- $\gamma \mathrm{H} 2 \mathrm{AX}$ antibody overnight, followed by Alexa Fluor 488-conjugated secondary antibodies for $1 \mathrm{~h}$. DAPI $(1 \mu \mathrm{g} / \mathrm{mL}$ in PBS) was added to the cells and incubated for another $30 \mathrm{~min}$ to stain the nuclei. The coverslip was mounted onto a glass slide, and then observed with an Olympus AX70 fluorescent microscope (Olympus).

\subsection{Measurement of ROS Production}

The level of Intracellular ROS was determined by using the $2^{\prime}, 7^{\prime}$-dichlorodihydrofluorescein diacetate (H2DCFDA) dye. Cells were seeded in a 96-well black bottom plate. After $24 \mathrm{~h}$, the cells were incubated with designated concentrations of cypermethrin for $1 \mathrm{~h}$. Then the medium was discarded and cells were washed with PBS. After that, cells were added with medium containing DCFDA dye $(20 \mu \mathrm{M})$. Then cells were incubated for $30 \mathrm{~min}$ at $37^{\circ} \mathrm{C}$. The medium was aspirated, and $200 \mu \mathrm{L}$ PBS was added to each well. Fluorescence intensity was measured in a plate reader at excitation of $485 \mathrm{~nm}$ wavelengths and emission of $528 \mathrm{~nm}$ wavelengths.

\subsection{Immunoblotting}

Cells were lysed with lysis buffer, then proteins were separated by $10 \%$ SDS-polyacrylamide gels (Mini-Protean II, Bio-Rad) and transferred to polyvinylidene fluoride (PVDF) Membrane (Millipore, Boston, MA, USA). After blocking with $5 \%$ non-fat milk in Tris-buffed saline with $0.1 \%(v / v)$ Tween-20 (TBST), membranes were probed with primary antibodies at $4{ }^{\circ} \mathrm{C}$ overnight, followed by incubation with horseradish peroxidase-conjugated secondary antibodies for $1 \mathrm{~h}$ at room temperature. After three washes, the proteins of interest were detected using an enhanced chemiluminescence kit.

\subsection{Hoechst 33342 Staining}

RAW cells were planted in 6 well plate and were treated with cypermethrin for $48 \mathrm{~h}$. Cells were treated with Hoechst 33342 staining at $1 \mathrm{mg} / \mathrm{mL}$ for $30 \mathrm{~min}$. Then, cells were washed twice with PBS and observed under an Olympus AX70 fluorescent microscope (Olympus). 


\subsection{Statistical Analysis}

Each experiment was conducted at least three times. Data were presented as mean \pm SD and statistical analysis of data was done with Student's $t$ test. $p$ values $<0.05$ were considered statistically significant.

\section{Conclusions}

In conclusion, this study demonstrated that cypermethrin induced cell cycle arrest and apoptosis in RAW 264.7 cells via mechanisms engaging ROS/oxidative, which caused DNA damage and subsequently JNK and ERK MAPK signaling pathways activation. Data from our study provide clear evidence showing the immunotoxic effects of cypermethrin on macrophages.

Acknowledgments: This work was supported by the National Natural Science Foundation of China (No. 31471297).

Author Contributions: Fang Huang, Qiaoyun Liu, Shujun Xie, Jian Xu, and Bo Huang performed the experiments; Yihua Wu and Dajing Xia conceived and designed the experiments; Fang Huang and Dajing Xia wrote the paper. All authors helped to prepare the paper and approved the final version.

Conflicts of Interest: The authors declare no conflict of interest.

\section{References}

1. Nasuti, C.; Gabbianelli, R.; Falcioni, M.L.; di Stefano, A.; Sozio, P.; Cantalamessa, F. Dopaminergic system modulation, behavioral changes, and oxidative stress after neonatal administration of pyrethroids. Toxicology 2007, 229, 194-205. [CrossRef] [PubMed]

2. Costa, L.G.; Giordano, G.; Guizzetti, M.; Vitalone, A. Neurotoxicity of pesticides: A brief review. Front. Biosci. 2008, 13, 1240-1249. [CrossRef] [PubMed]

3. Heudorf, U.; Angerer, J.; Drexler, H. Current internal exposure to pesticides in children and adolescents in Germany: Urinary levels of metabolites of pyrethroid and organophosphorus insecticides. Int. Arch. Occup. Environ. Health 2004, 77, 67-72. [CrossRef] [PubMed]

4. Carriquiriborde, P.; Diaz, J.; Mugni, H.; Bonetto, C.; Ronco, A.E. Impact of cypermethrin on stream fish populations under field-use in biotech-soybean production. Chemosphere 2007, 68, 613-621. [CrossRef] [PubMed]

5. Jaensson, A.; Scott, A.P.; Moore, A.; Kylin, H.; Olsen, K.H. Effects of a pyrethroid pesticide on endocrine responses to female odours and reproductive behavior in male parr of brown trout (Salmo trutta L.). Aquat. Toxicol. 2007, 81, 1-9. [CrossRef] [PubMed]

6. Sepici-Dincel, A.; Caglan Karasu Benli, A.; Selvi, M.; Sarikaya, R.; Sahin, D.; Ayhan Ozkul, I.; Erkoc, F. Sublethal cyfluthrin toxicity to carp (Cyprinus carpio L.) fingerlings: Biochemical, hematological, histopathological alterations. Ecotoxicol. Environ. Saf. 2009, 72, 1433-1439. [CrossRef] [PubMed]

7. Kan, Y.; Cengiz, E.I.; Ugurlu, P.; Yanar, M. The protective role of vitamin E on gill and liver tissue histopathology and micronucleus frequencies in peripheral erythrocytes of Oreochromis niloticus exposed to deltamethrin. Environ. Toxicol. Pharmacol. 2012, 34, 170-179. [CrossRef] [PubMed]

8. Lund, A.E.; Narahashi, T. Modification of sodium channel kinetics by the insecticide tetramethrin in crayfish giant axons. Neurotoxicology 1981, 2, 213-229. [PubMed]

9. Prashanth, M.S.; David, M. Impact of cypermethrin on $\mathrm{Na}^{+}-\mathrm{K}^{+}, \mathrm{Ca}^{2+}$ and $\mathrm{Mg}^{2+}$ ATPases in Indian major carp, Cirrhinus mrigala (Hamilton). Bull. Environ. Contam. Toxicol. 2010, 84, 80-84. [CrossRef] [PubMed]

10. Gupta, A.; Agarwal, A.K.; Shukla, G.S. Effect of quinalphos and cypermethrin exposure on developing blood-brain barrier: Role of nitric oxide. Environ. Toxicol. Pharmacol. 2000, 8, 73-78. [CrossRef]

11. Li, Y.F.; Pan, C.; Hu, J.X.; Li, J.; Xu, L.C. Effects of cypermethrin on male reproductive system in adult rats. Biomed. Environ. Sci. 2013, 26, 201-208. [PubMed]

12. Liu, L.; Hu, J.X.; Wang, H.; Chen, B.J.; He, Z.; Xu, L.C. Effects of $\beta$-cypermethrin on male rat reproductive system. Environ. Toxicol. Pharmacol. 2010, 30, 251-256. [CrossRef] [PubMed]

13. Maurya, S.K.; Mishra, J.; Tripathi, V.K.; Sharma, R.; Siddiqui, M.H. Cypermethrin induces astrocyte damage: Role of aberrant $\mathrm{Ca}^{2+}$, ROS, JNK, P38, matrix metalloproteinase 2 and migration related reelin protein. Pestic. Biochem. Physiol. 2014, 111, 51-59. [CrossRef] [PubMed] 
14. Mun, J.Y.; Lee, W.Y.; Han, S.S. Effects of cypermethrin on the dopaminergic neurons in the progressive hemiparkinsonian rats. Toxicol. Mech. Methods 2005, 15, 399-404. [CrossRef] [PubMed]

15. Jin, Y.; Zheng, S.; Pu, Y.; Shu, L.; Sun, L.; Liu, W.; Fu, Z. Cypermethrin has the potential to induce hepatic oxidative stress, DNA damage and apoptosis in adult zebrafish (Danio rerio). Chemosphere 2011, 82, 398-404. [CrossRef] [PubMed]

16. Yu, S.; Tang, S.; Mayer, G.D.; Cobb, G.P.; Maul, J.D. Interactive effects of ultraviolet-B radiation and pesticide exposure on DNA photo-adduct accumulation and expression of DNA damage and repair genes in Xenopus laevis embryos. Aquat. Toxicol. 2015, 159, 256-266. [CrossRef] [PubMed]

17. Singh, P.; Srivastava, A.K.; Singh, A.K. Cell cycle stage specific application of cypermethrin and carbendazim to assess the genotoxicity in somatic cells of Hordeum vulgare L. Bull. Environ. Contam. Toxicol. 2008, 81, 258-261. [CrossRef] [PubMed]

18. Kastan, M.B.; Canman, C.E.; Leonard, C.J. P53, cell cycle control and apoptosis: Implications for cancer. Cancer Metastasis Rev. 1995, 14, 3-15. [CrossRef] [PubMed]

19. Fernandez-Capetillo, O.; Lee, A.; Nussenzweig, M.; Nussenzweig, A. H2AX: The histone guardian of the genome. DNA Repair 2004, 3, 959-967. [CrossRef] [PubMed]

20. Redon, C.; Pilch, D.; Rogakou, E.; Sedelnikova, O.; Newrock, K.; Bonner, W. Histone H2A variants H2AX and H2AZ. Curr. Opin. Genet. Dev. 2002, 12, 162-169. [CrossRef]

21. Cowan, K.J.; Storey, K.B. Mitogen-activated protein kinases: New signaling pathways functioning in cellular responses to environmental stress. J. Exp. Biol. 2003, 206 Pt 7, 1107-1115. [CrossRef] [PubMed]

22. Hussell, T.; Bell, T.J. Alveolar macrophages: Plasticity in a tissue-specific context. Nat. Rev. Immunol. 2014, 14, 81-93. [CrossRef] [PubMed]

23. Finkel, T.; Holbrook, N.J. Oxidants, oxidative stress and the biology of ageing. Nature 2000, 408, $239-247$. [CrossRef] [PubMed]

24. Pi, J.; Zhang, Q.; Fu, J.; Woods, C.G.; Hou, Y.; Corkey, B.E.; Collins, S.; Andersen, M.E. ROS signaling, oxidative stress and Nrf2 in pancreatic beta-cell function. Toxicol. Appl. Pharmacol. 2010, 244, 77-83. [CrossRef] [PubMed]

25. Lei, S.; Liu, Y.; Liu, H.; Yu, H.; Wang, H.; Xia, Z. Effects of $N$-acetylcysteine on nicotinamide dinucleotide phosphate oxidase activation and antioxidant status in heart, lung, liver and kidney in streptozotocin-induced diabetic rats. Yonsei Med. J. 2012, 53, 294-303. [CrossRef] [PubMed]

26. Xia, Z.; Kuo, K.H.; Nagareddy, P.R.; Wang, F.; Guo, Z.; Guo, T.; Jiang, J.; McNeill, J.H. N-acetylcysteine attenuates $\mathrm{PKC} \beta 2$ overexpression and myocardial hypertrophy in streptozotocin-induced diabetic rats. Cardiovasc. Res. 2007, 73, 770-782. [CrossRef] [PubMed]

27. Fiordaliso, F.; Bianchi, R.; Staszewsky, L.; Cuccovillo, I.; Doni, M.; Laragione, T.; Salio, M.; Savino, C.; Melucci, S.; Santangelo, F.; et al. Antioxidant treatment attenuates hyperglycemia-induced cardiomyocyte death in rats. J. Mol. Cell. Cardiol. 2004, 37, 959-968. [CrossRef] [PubMed]

28. Chung, Y.M.; Bae, Y.S.; Lee, S.Y. Molecular ordering of ROS production, mitochondrial changes, and caspase activation during sodium salicylate-induced apoptosis. Free Radic. Biol. Med. 2003, 34, 434-442. [CrossRef]

29. Cooke, M.S.; Evans, M.D.; Dizdaroglu, M.; Lunec, J. Oxidative DNA damage: Mechanisms, mutation, and disease. FASEB J. 2003, 17, 1195-1214. [CrossRef] [PubMed]

30. Bennett, M.R. Reactive oxygen species and death: oxidative DNA damage in atherosclerosis. Circ. Res. 2001, 88, 648-650. [CrossRef] [PubMed]

31. McKelvey-Martin, V.J.; Green, M.H.; Schmezer, P.; Pool-Zobel, B.L.; de Meo, M.P.; Collins, A. The single cell gel electrophoresis assay (comet assay): A European review. Mutat. Res. 1993, 288, 47-63. [CrossRef]

32. Fernandez-Capetillo, O.; Celeste, A.; Nussenzweig, A. Focusing on foci: H2AX and the recruitment of DNA-damage response factors. Cell Cycle 2003, 2, 426-427. [CrossRef] [PubMed]

33. Fernandez-Capetillo, O.; Chen, H.T.; Celeste, A.; Ward, I.; Romanienko, P.J.; Morales, J.C.; Naka, K.; Xia, Z.; Camerini-Otero, R.D.; Motoyama, N.; et al. DNA damage-induced G2-M checkpoint activation by histone H2AX and 53BP1. Nat. Cell Biol. 2002, 4, 993-997. [CrossRef] [PubMed]

34. Wang, Y.; Liu, T.; Huang, P.; Zhao, H.; Zhang, R.; Ma, B.; Chen, K.; Huang, F.; Zhou, X.; Cui, C.; et al. A novel Golgi protein (GOLPH2)-regulated oncolytic adenovirus exhibits potent antitumor efficacy in hepatocellular carcinoma. Oncotarget 2015, 6, 13564-13578. [CrossRef] [PubMed] 
35. El-Deiry, W.S.; Tokino, T.; Velculescu, V.E.; Levy, D.B.; Parsons, R.; Trent, J.M.; Lin, D.; Mercer, W.E.; Kinzler, K.W.; Vogelstein, B. WAF1, a potential mediator of p53 tumor suppression. Cell 1993, 75, 817-825. [CrossRef]

36. Xia, M.; Knezevic, D.; Vassilev, L.T. p21 does not protect cancer cells from apoptosis induced by nongenotoxic p53 activation. Oncogene 2011, 30, 346-355. [CrossRef] [PubMed]

37. Antony, M.L.; Kim, S.H.; Singh, S.V. Critical role of p53 upregulated modulator of apoptosis in benzyl isothiocyanate-induced apoptotic cell death. PLoS ONE 2012, 7, e32267. [CrossRef] [PubMed]

38. Vousden, K.H.; Lu, X. Live or let die: the cell's response to p53. Nat. Rev. Cancer 2002, 2, 594-604. [CrossRef] [PubMed]

39. Boutros, T.; Chevet, E.; Metrakos, P. Mitogen-activated protein (MAP) kinase/MAP kinase phosphatase regulation: Roles in cell growth, death, and cancer. Pharmacol. Rev. 2008, 60, 261-310. [CrossRef] [PubMed]

40. Chen, C.H.; Chen, S.J.; Su, C.C.; Yen, C.C.; Tseng, T.J.; Jinn, T.R.; Tang, F.C.; Chen, K.L.; Su, Y.C.; Lee, K.I.; et al . Chloroacetic acid induced neuronal cells death through oxidative stress-mediated p38-MAPK activation pathway regulated mitochondria-dependent apoptotic signals. Toxicology 2013, 303, 72-82. [CrossRef] [PubMed]

41. Shen, H.M.; Liu, Z.G. JNK signaling pathway is a key modulator in cell death mediated by reactive oxygen and nitrogen species. Free Radic. Biol. Med. 2006, 40, 928-939. [CrossRef] [PubMed]

42. Singh, N.P.; McCoy, M.T.; Tice, R.R.; Schneider, E.L. A simple technique for quantitation of low levels of DNA damage in individual cells. Exp. Cell Res. 1988, 175, 184-191. [CrossRef]

(C) 2016 by the authors; licensee MDPI, Basel, Switzerland. This article is an open access article distributed under the terms and conditions of the Creative Commons Attribution (CC-BY) license (http:/ / creativecommons.org/licenses/by/4.0/). 